\title{
Genetic variation and phylogenetic relationships among domesticated and wild paddlefish (Polyodon spathula) populations
}

\author{
K. M. Kurta ${ }^{1}$, O. O. Malysheva1, I. Ya. Skrypkina ${ }^{2}$ \\ ${ }^{1}$ Ukrainian laboratory of quality and safety of AIC products, \\ National University of Life and Environmental Sciences of Ukraine, \\ 7, Mashinobudivnykiv Str., Chabany village, Kyiv region, Ukraine, 08162 \\ ${ }^{2}$ Institute of Molecular Biology and Genetics, NAS of Ukraine \\ 150, Akademika Zabolotnoho Str., Kyiv, Ukraine, 03143 \\ khrystyna.kurta@nubip.edu.ua,malisheva.sirota@gmail.com, inessa.skrypkina@gmail.com
}

\begin{abstract}
Aim. To determine the genetic variation and phylogenetic relationships among domesticated paddlefish populations from Ukraine and Poland with wild populations from the United States using microsatellite DNA markers. Methods. In total, 105 paddlefish individuals were analyzed using PCR technique, capillary electrophoresis, and statistical methods. Results. The evaluated mean number of alleles per locus $(\mathrm{Na})$ varied from 5.5 to 6.6 in the Polish and Ukrainian paddlefish stocks, respectively, whereas two-fold lower genetic polymorphism was demonstrated if compared to that found in wild population from the USA (11.1 alleles per locus). The mean observed (Ho) heterozygosity estimated in Ukrainian populations (0.709) was relatively close to those in the Polish (0.809) and wild (0.817) populations . Close genetic relationships were observed among the studied Ukrainian populations. The measured genetic similarity ranged from 0.908 (among populations from Kherson and Chernihiv regions) to 0.981 (among populations from Chernihiv and Vinnytsia regions). The Nei's genetic distances ranged from 0.019 (populations from Chernihiv and Vinnytsia regions) to 0.096 (populations from Kherson and Chernihiv regions). The constructed dendrogram demonstrated the genetic differences among hatchery-reared and natural paddlefish populations, which were separated into two single clusters according to their geographical origin. Conclusion. It has been revealed that Polish paddlefish population was more genetically distant from the studied Ukrainian populations of this species, which confirms the formation of Ukrainian and Polish populations from different parental individuals. The results obtained allow us to consider the investigated fish groups as a potential source of the exchange and enrichment of genetic resources of the paddlefish populations.
\end{abstract}

Ke y w or d s: paddlefish Polyodon spathula, DNA-markers, microsatellites, polymerase chain reaction, alleles, phylogenetic analysis

2020 K. M. Kurta et al.; Published by the Institute of Molecular Biology and Genetics, NAS of Ukraine on behalf of Biopolymers and Cell. This is an Open Access article distributed under the terms of the Creative Commons Attribution License (http://creativecommons.org/licenses/by/4.0/), which permits unrestricted reuse, distribution, and reproduction in any medium, provided the original work is properly cited 


\section{Introduction}

The purposeful management of the genetic resources is becoming increasingly important in animal husbandry and aquaculture to preserve biodiversity in hatchery-reared stocks. Growing demand for fishery products requires the expansion of the production of highly valuable objects for the producing of marketable products in a relatively short time $[1,2]$.

Currently, American paddlefish (Polyodon spathula), as a representative of Acipenseriformes species, is of high commercial importance, and its cultivation in aquaculture allows an increase in the productivity of fishing enterprises by rearing in polyculture with other valuable fishes $[3,4]$.

Artificial paddlefish reproduction is widespread in the United States for restocking and conservation of natural genetic resources, producing marketable products, and for sport fishing of this species. A similar strategy has evolved since the creation of the Mississippi Interstate Cooperative Resource Association (MICRA) in 1991 providing the management of natural paddlefish populations through artificial reproduction and maintenance of its genetic diversity $[5,6]$.

In turn, the development of paddlefish aquaculture particularly in Europe, Asia and Cuba, is mainly focused on the production of commodity products as black caviar and delicatessen meat to meet the needs of the domestic market and export [7, 8]. Meanwhile, in Ukraine the paddlefish aquaculture is becoming increasingly popular as an optimal alternative to sturgeon species. However, the main challenge in the aquaculture sector is the risk of reduction of genetic variability in farmed paddlefish populations due to small quantities of the genetic material imported from the USA and Russian Federation to establish its stocks. Likewise, in neighboring country Poland the broodstocks are relatively small and were formed from the progeny of a few spawners from Hungary $[4,12,16]$. Because of this, it is especially significant to evaluate genetic variation and identify genetic differences among paddlefish populations.

At present, the study of genetic processes occurring in paddlefish populations due to natural geographical isolation or under the influence of cultivation practice is at high of its development. The first main contribution proposed in the investigation of such genetic processes is the microsatellite DNA markers [9-14].

In population-genetic studies, microsatellites are widely used to determine genetic differentiation, carry out DNA identification and certification of species, and manage selection and breeding of valuable objects during their artificial reproduction [9, 15-18].

Based on the DNA analysis of paddlefish individuals, the controlled selection of spawner pairs can be performed in order to purposefully restore local populations and maintain genetic diversity of populations under artificial reproduction [11-14]. Additionally, the identification and assessment of genetic differences among the populations of natural reservoirs and farmed species will allow the establishment of phylogenetic relationships and determination of the origin of target objects for effective management of the genetic resources $[13,19-22]$. 
The purpose of this study is to determine the genetic variation and phylogenetic relationships among the domesticated and wild paddlefish (Polyodon spathula) populations by STRloci polymorphism.

\section{Materials and Methods}

\section{Fish Samples}

Samples (fin clips) were collected (105 in total) from paddlefish individuals of «Dnieper sturgeon fish hatchery named after acad. S.T. Artyushhyk» $(\mathrm{n}=32$, Kherson region, 2016), "Chernihivrybhosp» ( $\mathrm{n}=35$, Chernihiv region, 2017) and LTD Fish farm «Mercury» $(\mathrm{n}=38$, Vinnytsia region, 2017) [23]. The fin clips for the genetic investigation were stored in $97 \%$ ethanol at $-20^{\circ} \mathrm{C}$.

\section{DNA Extraction}

Genomic DNA was extracted («AmpliPrime» kit, Russian Federation) using silica-based method (SiO2) [24] and subjected to spectrophotometric reading (BioSpec Nano Spectrophotometer, Shimadzu, Japan) to assess the DNA quality (DNA concentration varied between 48 and $65 \mathrm{ng} / \mu \mathrm{l})$.

\section{PCR Amplification}

Multiplex PCR mix with a total volume of 20.0 $\mu l$ contained $50.0 \mathrm{mM}$ of Tris- $\mathrm{HCl}(\mathrm{pH} \mathrm{8.3)}$, $1.5 \mathrm{mM}$ of $\mathrm{MgCl}_{2}, 0.2 \mathrm{mM}$ of each dNTP, $5 \mathrm{pM}$ of forward and reverse primers and $1.5 \mathrm{U}$ of Taq-DNA polymerase (Thermo Scientific ${ }^{\mathrm{TM}}$, Lithuania). PCR amplification (PCR) was performed on the Veriti 96 Well termocycler (Applied Biosystems, USA) by standardized parameters: (a) initial denaturation $-5 \mathrm{~min}$, $95^{\circ} \mathrm{C}$; (b) 30 cycles, including denaturation $15 \mathrm{~s}, 95^{\circ} \mathrm{C}$; primers hybridization $-25 \mathrm{~s}$, $56{ }^{\circ} \mathrm{C}$; elongation $-5 \mathrm{~s}, 72{ }^{\circ} \mathrm{C}$ and (c) final elongation $-5 \mathrm{~min}, 72{ }^{\circ} \mathrm{C}$ [25].

The selected polymorphic microsatellites, namely Psp21, Psp26 Psp28, which are presented in GenBank ${ }^{\circledR}$ (Table 1), were co-amplified in a single multiplex PCR reaction. One primer (forward or reverse) from each pair was end-labeled with a fluorescent dye.

\section{Genotyping}

Amplified products were denatured with formamide (Sigma, USA), then separated and detected via capillary electrophoresis (ABI Prism 3130xl Genetic Analyzer, Applied Biosystems, USA). The DNA fragment size

Table 1. Specific information for the selected STR loci for individual identification and comparative analysis of paddlefish populations [10]

\begin{tabular}{l|l|l|l}
\hline \multicolumn{1}{c|}{ Locus } & \multicolumn{1}{|c|}{ № GenBank } & \multicolumn{1}{|c}{ Nucleotide sequence of primers $\left(5^{`} \rightarrow 3^{\prime}\right)$} & \multicolumn{1}{c}{ Allele Size Range (Bases) } \\
\hline Psp12 & AF406735.1 & $\begin{array}{l}\text { F:ATCTGATACAATCTTCACAGTCC } \\
\text { R: GAGTTCCAGCTCGCTCTCC }\end{array}$ & $218-228$ \\
\hline Psp21 & AF406736.1 & $\begin{array}{l}\text { F:TTCAGCAGGTAGTGAGACAGGCAG } \\
\text { R:TCAAGTCCCATCCACTCT }\end{array}$ & $142-170$ \\
\hline Psp26 & AF406737.1 & $\begin{array}{l}\text { F:TCGGTGTTTGTGTGTGTGTATGC } \\
\text { R:TGGTTCCAGTTTCGCTCATCC }\end{array}$ & $224-260$ \\
\hline Psp28 & AF406738.1 & $\begin{array}{l}\text { F:CAAAGGCATCCCCTACCAC } \\
\text { R:GCTGGACAAAAAGTATGGAGTGC }\end{array}$ \\
\hline
\end{tabular}


was analyzed with the GeneScanTM 500 LIZ size standard and GeneMapper analysis Version 3.7 Software (Applied Biosystems, USA).

\section{Statistical analysis}

Number of alleles per locus (Na), heterozygosity (observed (Ho) and expected (He)), Wright's fixation index (Fis) [26], probability value $(\mathrm{P})$, Hardy-Weinberg equation (HWE) values were calculated using software MS Excel 2010.PowerStats V12 (Promega), Cervus v. 3.0.3, GENALEX 6.5, Statistica 8.0 (StatSoft, Tulsa, USA) [27-30].

Based on the allele frequencies, the genetic distances and coefficient of genetic identity were computed in agreement with Nei [31].
The Principal Coordinate Analysis (PCoA) was performed using GENALEX 6.5 program. The Neighbor-joining method (NJ) was used to construct the dendrogram of genetic distances between the studied fish groups using the POPTREEW Software [32].

\section{Results}

The comparative study were carried out between three cultured stock from Ukrainian regions (obtained as a result of own studies), two stocks from Poland studied by Kaczmarczyk D. (Kaczmarczyk, 2012): Pogórze, Silesian Voivodeship $(\mathrm{n}=24)$ and Wasosze, Kujawsko-Pomorskie Voivodeship $(n=29)$ and wild populations from the United States investigated by Heist E. J. (Heist, 2002).

Table 2. Comparison of genetic diversity indices for Ukrainian and Polish (Kaczmarczyk, 2012) populations with wild populations from the USA (Heist, 2002)

\begin{tabular}{|c|c|c|c|c|}
\hline Origin of the population & $\begin{array}{c}\mathrm{Na} \\
(\mathrm{mean} \pm \mathrm{SE}) \\
\end{array}$ & $\begin{array}{c}\text { Ho } \\
(\text { mean } \pm \text { SE) }\end{array}$ & $\begin{array}{c}\mathrm{He} \\
(\text { mean } \pm \mathrm{SE}) \\
\end{array}$ & $\begin{array}{c}\text { Fis } \\
(\text { mean } \pm \mathrm{SE})\end{array}$ \\
\hline \multicolumn{5}{|c|}{ Ukraine } \\
\hline $\begin{array}{l}\text { «Dnieper sturgeon fish hatchery named after acad. S.T. } \\
\text { Artyushhyk» (Kherson reg.) } \mathrm{n}=32\end{array}$ & $7.0 \pm 1.527$ & $0.729 \pm 0.211$ & $0.608 \pm 0.143$ & $-0.159 \pm 0.129$ \\
\hline «Chernigiv rybhosp» (Chernihiv reg.), $\mathrm{n}=35$ & $5.7 \pm 1.330$ & $0.724 \pm 0.142$ & $0.650 \pm 0.050$ & $-0.092 \pm 0.144$ \\
\hline LTD Fishfarm «Mercury», (Vinnytsia reg.), $\mathrm{n}=38$ & $5.7 \pm 1.330$ & $0.675 \pm 0.133$ & $0.589 \pm 0.099$ & $-0.121 \pm 0.186$ \\
\hline Mean for populations & $6.1 \pm 0.186$ & $0.709 \pm 0.017$ & $0.616 \pm 0.018$ & $-0.124 \pm 0.019$ \\
\hline \multicolumn{5}{|c|}{ Poland } \\
\hline $\begin{array}{l}\text { Wasosze, Kujawsko-Pomorskie } \\
(\mathrm{n}=29)\end{array}$ & $6.3 \pm 1.450$ & $0.815 \pm 0.080$ & $0.713 \pm 0.092$ & $-0.153 \pm 0.047$ \\
\hline $\begin{array}{l}\text { Pogorze, Silesian Voivodeship } \\
(\mathrm{n}=24)\end{array}$ & $4.7 \pm 0.330$ & $0.803 \pm 0.099$ & $0.686 \pm 0.059$ & $-0.062 \pm 0.116$ \\
\hline Mean for populations & $5.5 \pm 0.800$ & $0.809 \pm 0.006$ & $0.699 \pm 0.014$ & $-0.108 \pm 0.046$ \\
\hline \multicolumn{5}{|c|}{ USA } \\
\hline Big Muddy and Mississipi rivers, Illinois, $\mathrm{n}=28$ & $10.0 \pm 1.730$ & $0.821 \pm 0.074$ & $0.809 \pm 0.056$ & $-0.013 \pm 0.022$ \\
\hline North Dakota, Missouri river, $\mathrm{n}=39$ & $12.3 \pm 2.400$ & $0.845 \pm 0.043$ & $0.841 \pm 0.041$ & $0.004 \pm 0.009$ \\
\hline $\begin{array}{l}\text { Bayou Nezpique and Mermentau River, Louisiana, } \\
\mathrm{n}=45\end{array}$ & $11.0 \pm 2.080$ & $0.785 \pm 0.015$ & $0.789 \pm 0.034$ & $0.002 \pm 0.044$ \\
\hline Mean for populations & $11.1 \pm 0.665$ & $0.817 \pm 0.017$ & $0.813 \pm 0.015$ & $-0.002 \pm 0.005$ \\
\hline
\end{tabular}

Note: Departures from the Hardy-Weinberg equilibrium $(\mathrm{p} \leq 0.05)$ within investigated stocks. 
For the comparative studies, the populations were chosen from different geographic regions, including Bayou Nezpique, Mermentau River, Louisiana $(\mathrm{n}=45)$; Big Muddy and Mississippi, Illinoice $(\mathrm{n}=28)$; Missouri, North Dakota $(\mathrm{n}=43)$; Red River near Natchitoches, Louisiana $(\mathrm{n}=48)$; Red River below Lake Texoma, Oklahoma $(\mathrm{n}=41)$; Grand Lake Neosho River, Oklahoma $(\mathrm{n}=35)$.

Table 2 shows that the mean number of alleles per locus $(\mathrm{Na})$ varied from 5.5 to 6.6 in the Polish and Ukrainian paddlefish stocks, respectively, though it demonstrated a lower genetic polymorphism compared to that found in wild population from the USA (11.1 alleles per locus).

The mean observed heterozygosity (Ho) estimated in the Ukrainian stocks (0.709) was relatively close to those in the Polish stocks (0.809) and in wild populations (0.817). Meanwhile, the average observed heterozygosity was higher than expected for both Ukrainian $(\mathrm{Ho}=0.709 ; \mathrm{He}=0.616)$ and Polish (Ho $=0.809 ; \mathrm{He}=0.699)$ paddlefish stocks. Similarly, the Wright's fixation index $\left(\mathrm{F}_{\mathrm{IS}}\right)$ on average confirmed the predominance of heterozygous genotypes in domesticated populations from Ukraine (-0.124) and Poland $(-0.108)$. The results for the populations from the USA showed that the average observed and expected heterozygosity values were at 0.817 and 0.813 , respectively, indicating that the genotype frequencies in wild stocks were in Hardy-Weinberg equilibrium (HWE), as evidenced by the fixation index $\left(\mathrm{F}_{\mathrm{IS}}=-0.002\right)$.

Based on the previously calculated frequencies for the identified allelic variants (Kurta, 2019), the Nei's genetic distances and genetic identity among Ukrainian paddlefish populations were revealed (Table 3 ).
Table 3. The pairwise Nei's genetic distance (below diagonal) and identity (above diagonal) matrix among Ukrainian paddlefish populations

\begin{tabular}{l|c|c|c}
\hline Origin of the population & $\begin{array}{c}\text { Kherson } \\
\text { region }\end{array}$ & $\begin{array}{c}\text { Chernihiv } \\
\text { region }\end{array}$ & $\begin{array}{c}\text { Vinnytsia } \\
\text { region }\end{array}$ \\
\hline Kherson region & - & 0.908 & 0.937 \\
\hline Chernihiv region & 0.096 & - & 0.981 \\
\hline Vinnytsia region & 0.065 & 0.019 & - \\
\hline
\end{tabular}

It has been established that local populations demonstrated a high level of genetic similarities, which signifies the common origin of these fish groups. The maximum level of the genetic similarity was determined between Chernihiv and Vinnytsia populations at 0.981 , whereas the minimum level of the genetic similarity was observed between Kherson and Chernihiv populations at 0.908 . The genetic similarity among investigated groups of paddlefish from Kherson and Vinnytsia regions was 0.937 . According to the analysis of genetic distances for the studied populations, this index ranged from 0.019 (Chernihiv and Vinnytsia regions) to 0.096 (Kherson and Chernihiv regions), whereas among paddlefish populations from Kherson and Vinnytsia it was 0.065 . The increased genetic identity of Ukrainian paddlefish populations is characterized by the presence of predominantly similar allelic variants and their frequency values at the studied loci.

The Principal Coordinate Analysis (PCoA) has been used to visualize the genetic relationships measured by Nei's genetic distance (Fig. 1).

The dissimilarity matrix used as input depicts on the plot shows that the population originated from Kherson region is more distant from those originated from the farms in Chernihiv and Vinnytsia regions. 


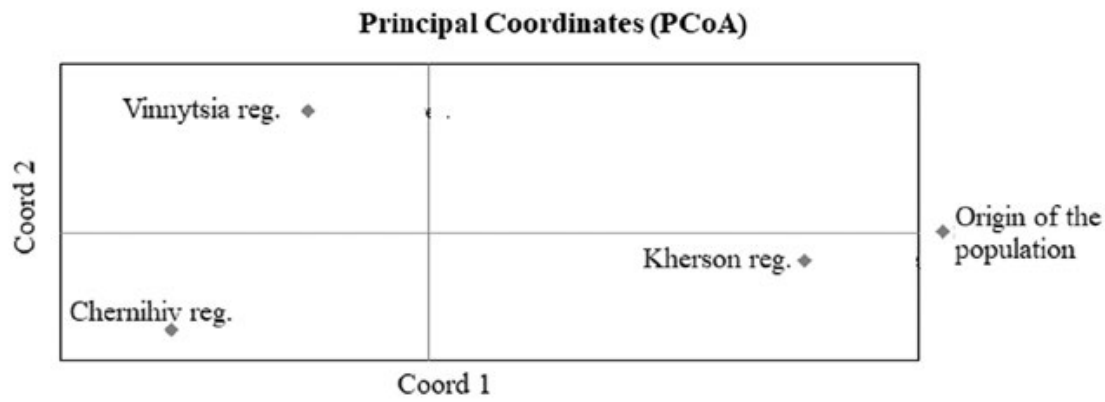

Fig. 1. Principal Coordinate Analysis (PCoA) based on Nei genetic distances for three paddlefish populations farmed in Ukraine

Phylogenetic analysis of Ukrainian populations using the neighbor-joining method (Fig. 2) showed that Chernihiv and Vinnytsia populations constitute a single cluster. In turn, the Kherson population formed a separate cluster.

Overall, the results of the research showed that the detected genetic distances are a consequence of the features of introduction of domesticated paddlefish populations within different geographic location in Ukraine. A high genetic identity among the three paddlefish populations confirms their common origin. The phylogenetic analysis showed that the investigated individuals of paddlefish populations from the Chernihiv and Vinnytsia regions were grouped into a single cluster. The data obtained indicate that these populations originate from one stock and have common parental individuals. At the same time, the population from the Kherson region appeared more genetically distant, perhaps, due to the genetic material additionally imported to this region, which is confirmed by historical aspects of paddlefish introduction in Ukrainian fish farms [8, 32].

Meanwhile, the additional comparison allowed the establishing of the genetic relationships between paddlefish population from Ukraine and Poland and natural populations from the United States based on three microsatellite DNA-loci (Psp21, Psp26, Psp28).

The distribution of genetic heterogeneity among paddlefish populations from Ukraine, Poland and natural populations from the USA

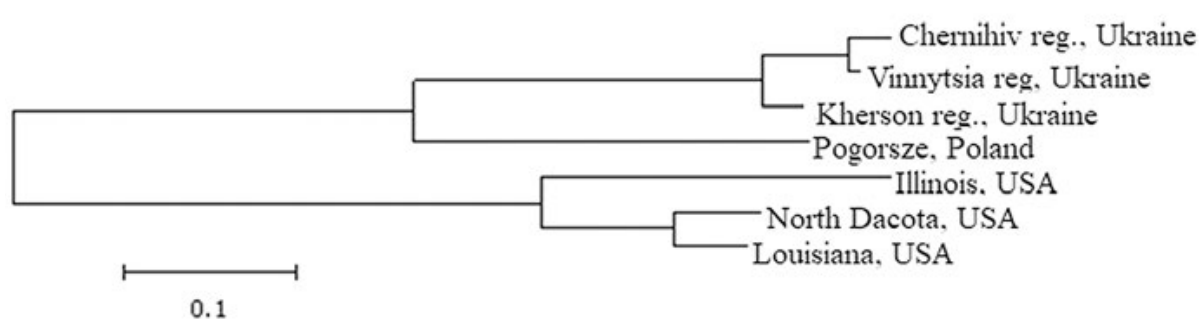

Fig. 2. Neighbor-joining dendrogram of the genetic distances among domesticated and wild paddlefish populations

Note: The stock from Wasosze (Poland) was excluded from phylogenetic analysis, since there is no data on allele frequencies. 
showed that domesticated and natural populations fall into different clusters according to their population membership. At the same time, the Polish population was more genetically distant from the studied Ukrainian paddlefish populations. Such results are similar to those obtained in the D. Kaczmarczyk studies [14] and could be a consequence of the formation of Ukrainian and Polish brood populations from different parental individuals.

Analysis of the genetic relationships among paddlefish populations indicated the genetic delimitation of Ukrainian individuals from natural groups. Similarly, the genetic distances were found between Polish and natural populations. Such results are observed as a consequence of differences in the allele frequency spectrum identified in the gene pool of analyzed populations.

\section{Discussion}

The evaluated genetic variation in Ukrainian domesticated populations was compared with the respective values observed in Polish paddlefish populations and natural populations of this species from the USA. The mean number of alleles per locus was significantly lower in Ukrainian (6.6) and Polish (5.5) populations in comparison to the natural populations (11.1). These results indicate that almost a two-fold lower genetic variation was observed within domesticated populations from Ukraine and Poland than for the populations from natural reservoirs. The analysis of heterozygosity across the examined populations showed that the mean observed heterozygosity (Ho) estimated in Ukrainian populations (0.709) was relatively close to those in Polish (0.809) and wild populations $(0.817)$. Moreover, the pro- portion of Ho to He rates within domesticated stocks indicated the excess of heterozygous genotypes over the homozygous for both Ukrainian $(\mathrm{Ho}=0.709 ; \mathrm{He}=0.616)$ and Polish ( $\mathrm{Ho}=0.809 ; \mathrm{He}=0.699)$ paddlefish stocks. These findings were confirmed by values of Wright's fixation index $\left(\mathrm{F}_{\mathrm{IS}}\right)$ in Ukrainian $(-0.124)$ and Polish (-0.108) populations. Despite the fact that the data obtained show high heterozygosity levels for the examined populations, keen attention should be paid to the genetic control of paddlefish breeding in order to prevent the loss of its genetic variability in the farmed populations.

The phylogenetic relationships of cultured paddlefish populations from Ukraine and Poland with natural populations from the United States were determined using three microsatellite DNA markers: Psp21, Psp26 and Psp28. The results demonstrate the close genetic relationships among Ukrainian paddlefish populations, confirming their common origin. Meanwhile, the genetic differences were found among Ukrainian and Polish populations, which allows considering the fish groups as a potential source for the exchange and enrichment of the paddlefish genetic resources.

The genetic distinctiveness between the paddlefish populations from Ukraine and Poland and natural populations from the United States indicate differences in the allele pool, in particular, low allelic diversity and allele frequency spectrum, due to cultivation of this species of fish in aquaculture.

Therefore, monitoring of the genetic processes in stocked paddlefish will allow an effective management of the genetic resources and preservation of the biodiversity that may be lost due to reproductive isolation and uncon- 
trolled selection of spawning pairs for breeding. Particular attention should be given to selective and breeding work with the usage of genotyping of parental individuals for further formation of productive paddlefish brood stock. We recommend using the investigated microsatellites loci in the study of Ukrainian populations to analyze additional hatchery-reared brood populations of paddlefish from other geographic locations where the species was introduced.

\section{Acknowledgement}

We are grateful to chief fish farmers, namely V. Babenko ("Chernihivrybhosp", Chetnihiv region), B. Hrishyn ("Fish Farm Mercury", Vinnytsya region) and K. Moshniahul for their help in collecting the biological material for paddlefish DNA analysis.

\section{REFERENCES}

1. Barmintseva AE, Mugue NS. The Use of Microsatellite Loci for Identification of Sturgeon Species (Acipense-ridae) and Hybrid Forms. Genetics. 2013;9 (49):1093-105.

2. FAO. The Second Report on the State of the World's Animal Genetic Resources for Food and Agriculture, edited by B.D. Scherf\& D. Pilling. FAO Commission on Genetic Resources for Food and Agriculture Assessments. Rome. 2015; 604 p.

3. Pikitch E, Doukakis P, Lauck l, Chakraborty P, Erickson DL. Status, trends and management of sturgeon and paddlefish fisheries. Fish Fish. 2005; 6: 233-265. doi.:10.1111/j.1467-2979.2005.00190.x

4. Mims S, William L, Shelton. Paddlefish Aquaculture: Wiley-Blackwell. 2015; 320 p.

5. Abdul-Muneer PM. Application of Microsatellite Markers in Conservation Genetics and Fisheries Management: Recent Advances in Population Structure Analysis and Conservation Strategies. Genet Res Int. 2014; 2014: 691-759.
6. Slos BL, Klumb RA, Heist EJ. Genetic Conservation and Paddlefish Propagation. American Fisheries Society. 2009; 66: 307-27.

7. Vedrasco A, Lobchenko V, Billard R. Introductions etelevage du poisson-spatulePolyodonspathulaen Europe. Aquatic Living Resources. 2001; 14: 383-90.

8. Onuchenko $O$, Tretiak $O$, Kuleshov $O$. Fundamentals of paddlefish (Polyodonspathula, Walbaum) fisheries: a monograph. Kyiv. VyshchaOsvita. 2003;111p.

9. Chistiakov DA, Hellemans B, Volckaert FAM. Microsatellites and their genomic distribution, evolution, function and applications: A review with special reference to fish genetics. Aquaculture. 2006; 255 (1-4): 1-29.

10. Heist EJ, Nicholson EH, Sipiorski JT, Keeney DB. Microsatellite markers for the paddlefish (Polyodonspa-thula). Conservation Genetics. 2002; 3: 205-7.

11. Heist EJ, Mustapha A. Genetic Structure in Paddlefish Inferred from DNA Microsatellite Loci, Transactions of the American Fisheries Society. 2008; 137 (3): 909-15.

12. Kaczmarczyk D., Kohlmann K., Kersten P., Lucsyfski M. Polymorphism of microsatellite loci - a tool in studying biodiversity of paddlefish aquaculture broodstock. Environmental Biotechnology. 2007; 3: $44-48$.

13. Kaczmarczyk D., Luczynski M., Brzuzan P. Genetic variation of three paddlefish (PolyodonspathulaWalbaum) populations based on microsatellite DNA analysis, Czech Journal of Animal Science. 2012; 57: 345-352.

14. Kaczmarczyk D. Selection of optimal spawning pairs to maintain genetic variation among captive populations of Acipenseridae based on the polymorphism of microsatellite loci. Arch Polish Fisheries. 2016; 24: 77-84.

15. Milner ML, McIntosh EJ, Crisp MD, Weston PH, Rossetto M. Microsatellite variation for phylogenetic, phylogeographic and population-genetic studies in Lomatia (Proteaceae). Australian Syst Bot. 2013;26 (3): 186-95.

16. Krieger J, Hett AK, Fuerst PA, Artyukhin E, Ludwig $A$. The molecular phylogeny of the order Acipenseri- 
formes revisited. J Appl Ichthyol; 2008, 24 (1): 36-45.

17. Askari G, Shabani A, Kolangi H, Miandare. Application of molecular markers in fisheries and aquaculture. Sci J Animal Sci. 2013; 2 (4): 82-8.

18. Dudu A, Georgescu SE, Costache M. Evaluation of genetic diversity in fish using molecular markers. In : Molecular Approaches to Genetic Diversity. InTech. 2015: 163-93.

19. Caudron A, Champigneulle A, Vigier L, Hamelet V, Guyomard R. Early effects of the strategies of creating a genetic refuge and direct translocation for conserving and restoring populations of native brown trout. Freshwa-ter Biology. 2012; 14p.

20. Fain SR, Straughan DJ, Hamlin BC, Hoesch RM, LeMay JP. Forensic genetic identification of sturgeon caviars traveling in world trade. Conserv Genet. 2013; 14: 855-74.

21. Johnson TA, Iyengar A. Phylogenetic evidence for a case of misleading rather than mislabeling in caviar in the United Kingdom. J Forensic Sci. 2015; 60 (1):248-53.

22. Zheng X, Schneider K, Lowe JD, Gomelsky B, Mims $S D, B u S$. Genetic structure among four populations of paddlefish, Polyodonspathula (Actinopterygii: Acipenseriformes: Polyodontidae), based on disomic microsatel-lite markers. Acta Ichthyol Piscat. 2014;44 (3):213-9.

23. Kurta KhM, Malysheva OO, Yevtushenko MYu, Spyrydonov VG. Allelic polymorphism of Ukrainian populations of Paddlefish (Polyodonspathula). Hydrobiol J. 2019; 55 (3): 14-9.

24. Carter MJ, Milton ID. An inexpensive and simple method for DNA purifications on silica particles. Nucleic Acids Res. 1993;21:1044-6.

25. Kurta K, Malysheva O, Spyrydonov V. Optimization of polymerase chain reaction's conditions for studies of paddlefish (Polyodonspathula) microsatellite DNA. Animal Biol. 2017; 2 (19): 56-63.

26. Wright $S$. The genetical structure of populations. Ann Eugenics. 1951;(15):323-54.

27. Kalinowski ST, Taper ML, Marshall TC. Revising how the computer program CERVUS accommodates ge-notyping error increases success in paternity assignment. Mol Ecol. 2007;16 (5): 1099-106.
28. Marshall TC, Slate J, Kruuk LEB, Pemberton JM. Statistical confidence for likelihood-based paternity inference in natural populations, Mol Ecol. 1998:639-55.

29. Peakall R, Smouse PE. GENALEX 6: genetic analysis in Excel. Population genetic software for teaching and research. Mol Ecol Notes. 2006; 6: 288-95.

30. Peakall R, Smouse PE. GenAlEx 6.5: genetic analysis in Excel. Population genetic software for teaching and research-an update. Bioinformatics. 2012; 28 (19): 2537-9.

31. Nei M. Genetic distance between populations. AmNaturalist. 1972;106:283-392.

32. Takezaki N, Nei M, Tamura K. POPTREEW: Web Version of POPTREE for constructing population trees from allele frequency data and computing some other quantities. Mol Biol Evol. 2014;31(6): 1622-4.

33. Tretyak $O M$. Fish-breeding and biological bases of formation and exploitation of paddlefish broodstock (Polyodonspathula, Walbaum) under the introduction conditions. Fisheries Science of Ukraine. 2009; 3: 4-20.

\section{Генетична різноманітність та філогенетичні} взаємозв'язки між доместикованими та дикими популяціями веслоноса (Polyodon spathula)

\author{
Х. М. Курта, О. О. Малишева, І. Я. Скрипкіна
}

Мета. Провести аналіз генетичного різноманіття та філогенетичних зв'язків доместикованих популяцій 3 України та Польщі із дикими популяціями зі США за мікросателітними ДНК-маркерами. Методи. Всього було проаналізовано 105 особин веслоноса, використовуючи методику ПЛР, капілярний електрофорез та статистичні методи досліджень. Результати. Визначено середню кількість алелів на локус (Na) для українських і польських популяцій, яка становила 6.1 та 5.5, відповідно, що вказувало на нижчий рівень поліморфізму порівняно з природними популяціями, для яких даний показник був майже вдвічі вищим і в середньому становив - 11.1 алеля. Значення спостережуваної гетерозиготності (Но), визначене у штучно культивованих популяціях з України (0.709) та Польщі (0.809) були наближеними до рівня спостере- 
Genetic variation and phylogenetic relationships among domesticated and wild paddlefish (Polyodon spathula) populations

жуваної генетрозиготності у диких популяціях (0.817). Встановлено, що для досліджуваних українських популяцій спостерігаються високі рівні генетичної подібності. Зокрема, розраховані значення генетичної схожості коливалися від 0.908 (між популяціями 3 Херсонської та Чернігівської областей) до 0.981 (між популяціями з Чернігівської та Вінницької областей). Показник генетичних дистанцій за Nеі коливався від 0.019 (між популяціями з Чернігівської та Вінницької областей) до 0.096 (між популяціями з Херсонської та Чернігівської областей). Згідно побудованої дендрограми генетичних взаємозв'язків спостерігається розподіл доместикованих та природних популяцій на окремі кластери відповідно до їх географічного походження. Висновки. Було визначено, що польські популяції були генетично більш віддаленими, у порівнянні з українськими, що підтверджує особливості формування українських та польських популяцій від різних вихідних батьківських особин. Отримані результати дозволяють розглядати дані групи риб, як потенційне джерело для обміну та збагачення генетичними ресурсами популяцій веслоноса.

Кл юч ов і сл ов а: веслоніс (Polyodon spathula), ДНК-маркери, мікросателіти, полімеразна ланцюгова реакція, алелі, філогенетичний аналіз

Генетическое разнообразие и филогенетические взаимосвязи между доместицированными и дикими популяциями веслоноса (Polyodon spathula)

К. Н. Курта, О. А. Малышева, И. Я. Скрипкина

Цель. Провести анализ генетического разнообразия и филогенетических связей доместицированных популяций веслоноса из Украины и Польши с дикими популяциями из США по микросателитным ДНКмаркерам. Методы. Всего было проанализировано 105 особей веслоноса, используя методику ПЦР, капиллярный электрофорез и статистические методы исследований. Результаты. Определено среднее количество аллелей на локус $(\mathrm{Na})$ для украинских и польских популяций, которое составляло 6.1 и 5.5, соответственно, что указывало на более низкий уровень полиморфизма по сравнению с природными популяциями, для которых данный показатель был почти вдвое выше и в среднем составлял - 11.1 аллеля. Значения наблюдаемой гетерозиготности (Но), определенные в искусственно культивируемых популяциях из Украины (0.709) и Польши (0.809), были приближенными к уровню наблюдаемой гетерозиготности в диких популяциях (0.817). Установлено, что для исследуемых украинских популяций наблюдаются высокие уровни генетического сходства. В частности, рассчитанные значения генетического сходства колебались от 0.908 (между популяциями из Херсонской и Черниговской областей) до 0.981 (между популяциями из Черниговской и Винницкой областей). Показатель генетических дистанций по Nei колебался от 0.019 (между популяциями из Черниговской и Винницкой областей) до 0.096 (между популяциями из Херсонской и Черниговской областей). Согласно построенной дендрограммы генетических взаимосвязей наблюдается распределение одомашненных и диких популяций на отдельные кластеры в соответствии с их географическим происхождением. Выводы. Было определено, что польские популяции были генетически более отдаленным, по сравнению с украинскими, что подтверждает особенности формирования украинских и польских популяций от различных исходных родительских особей. Полученные результаты позволяют рассматривать данные группы рыб, как потенциальный источник для обмена и обогащения генетическими ресурсами популяций веслоноса.

Кл юч е в ы е сл ов а: веслонос (Polyodon spathula), ДНК-маркеры, микросателлиты, полимеразная цепная реакция, аллели, филогенетический анализ

Received 25.01.2020 